\title{
ZUHUD TAPI KAYA DALAM PERSPEKTIF HADIS
}

\author{
Eko Siswanto \\ STAIN Al-Fatah Jayapura \\ Jl. Merah Putih Buper, Yabansai, Heram, Kota Jayapura, 99224, Papua, Indonesia \\ Email: siswantoeko44@yahoo.co.id
}

\begin{abstract}
This paper talks about Zuhud. Zuhud is the noble nature of believers because it is not deceived by the world with all the delights whether the property, women, and thrones. Zuhud does not mean leaving the world. However, the believer and people who do good deeds in the world, prospering the earth, and doing for the benefit, then achieve the results in the world in the form of halal facilities and pleasures in the world. Imam Al-Ghazali said there were 3 signs of zuhud. Firstly, not happy with what was and not sad because of things that were lost. Secondly, it is the same side of the person who denounces and denounces it, both in relation to property and position. Thirdly, it should always be with God and his heart is dominated by the deliciousness of obedience. Since the heart cannot be free from love, whether it is love for God or love for the world. Zuhud in life was modeled by his companions, such as Abu Bakr, Umar, Uthman bin Affan, and Abdurrahman bin Auf. They are some friends who are wealthy, but do not take all their wealth for themselves and their families.
\end{abstract}

Keywords: Zuhud, Faith, World

\begin{abstract}
Abstrak
Tulisan ini membahas tentang Zuhud. Zuhud merupakan sifat mulia orang beriman karena tidak tertipu oleh dunia dengan segala kelezatannya baik harta, wanita, maupun tahta. Zuhud bukan berarti meninggalkan dunia. Tapi, orang beriman dan beramal salih di dunia, memakmurkan bumi, dan berbuat untuk kemaslahatan, kemudian mereka meraih hasilnya di dunia berupa fasilitas dan kenikmatan yang halal di dunia. Imam Al-Gazali menyebutkan ada 3 tanda-tanda zuhud, yaitu: pertama, tidak bergembira dengan apa yang ada dan tidak bersedih karena hal yang hilang. Kedua, sama saja di sisinya orang yang mencela dan mencacinya, baik terkait dengan harta maupun kedudukan. Ketiga, hendaknya senantiasa bersama Allah dan hatinya lebih didominasi oleh lezatnya ketaatan. Karena hati tidak dapat terbebas dari kecintaan, apakah cinta Allah atau cinta dunia. Kehidupan zuhud ini dicontoh oleh para sahabatnya: Abu Bakar, Umar, Usman bin Affan, dan Abdurrahman bin Auf. Mereka adalah beberapa sahabat yang kaya raya, tetapi tidak mengambil semua harta kekayaannya untuk diri sendiri dan keluarganya.
\end{abstract}

Kata Kunci: Zuhud, Iman, Dunia

\section{Pendahuluan}

Zuhud adalah salah satu akhlak utama seorang muslim. Terutama saat di hadapannya terbentang lebar kesempatan untuk meraih dunia dengan segala macam perbendaharaannya. Apakah itu kekuasaan, harta, kedudukan, dan segala fasilitas lainnya. Karenanya, zuhud adalah karakteristik dasar yang membedakan antara seorang mukmin sejati dengan mukmin awam. Jika tidak memiliki keistimewaan dengan karakteristik ini, seorang mukmin tidak dapat dibedakan lagi dari manusia kebanyakan yang terkena fitnah dunia.

Banyak orang yang salah paham terhadap zuhud. Banyak yang mengira kalau zuhud adalah meninggalkan harta, 
menolak segala kenikmatan dunia, dan mengharamkan yang halal. Padahal Islam mengharuskan umatnya agar memakmurkam bumi, bekerja, dan menguasai dunia, tetapi pada saat yang sama tidak tertipu oleh dunia. Segala yang halal itu jelas dan segala yang haram itu jelas, di antara keduanya ada yang syubhat yang harus kita jauhi dan tinggalkan.

Zuhud juga sering diartikan oleh banyak orang sebagai ungkapan atau refleksi sikap yang anti dunia bahkan menjauh dari dunia itu sendiri, sehingga menimbulkan kesan seakan-akan bahwa seseorang yang sedang belajar untuk mempunyai sikap zuhud ini harus mengosongkan diri dari segala hal yang berbau keduniawian, kesan selanjutnya bahwa ia harus menjadi seorang yang miskin, berpakaian lusuh, compangcamping, penuh tambalan dan sebagainya.

Di sisi lain banyak ayat-ayat Alquran dan hadis-hadis Nabi yang mengingatkan bahayanya dunia dalam kehidupan manusia jika tidak disikapi dengan sebuah pandangan bahwa dunia seisinya ini adalah sekedar sarana belaka untuk mencari bekal kehidupan abadi kelak di akhirat "Al-dunyā mazra 'ah al-ākhirah" dunia adalah ladangnya akhirat.

Ada yang memberikan pengertian bahwa zuhud adalah menjauhkan diri dari kesenangan duniawi untuk beribadah kepada Allah dari sesuatu yang disayangi yang bersifat material atau kemewahan duniawi dengan mengharap dan menginginkan sesuatu wujud yang lebih baik dan bersifat spiritual atau kebahagiaan akhirat.

Dengan beragamnya pemahaman tentang zuhud dalam kehidupan kita, maka artikel ini berupaya untuk memberikan penjelasan mengenai zuhud tersebut dalam perspektif hadis dengan menggunakan metode takhrïj hadīs bi al-lafż. Sehingga pada akhirnya kita akan mendapatkan pengertian zuhud yang sebenarnya.

\section{Takhrīj Hadī̇ bi al-Laf:̧}

Maksud dari Takhrīj dalam pembahasan ini adalah kegiatan penelusuran suatu hadis melalui kitab-kitab hadis sebagai sumber utamanya, kemudian dari kitab atau sumber tersebut dikemukakan secara lengkap mengenai matn dan sanad hadis yang bersangkutan. ${ }^{1}$

Adapun metode yang digunakan dalam penelusuran hadis-hadis yang berkaitan dengan zuhud adalah melalui takhrīj bi al-lafz̧ (takhrïj dengan kata) dengan menggunakan kamus al-Mu jam alMufahras li al-Alfāz al-Hadīs al-Nabaw̄̄ yang disusun oleh Arnold John Wensink. Maksud takhrīj dengan kata adalah takhrīj

${ }^{1}$ M. Syuhudi Ismail, Metodologi Penelitian Hadis Nabi (Cet. I; Jakarta: Bulan Bintang, 1992), 43. 
dengan kata benda atau kata kerja bukan kata sambung dalam bahasa Arab. ${ }^{2}$ Dalam penelusuran ini penulis menggunakan kata

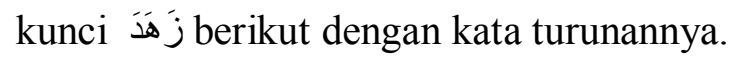
Setelah penulis menelusuri di kitab al-Mu ‘jam al-Mufahras li al-Alfāz al-Hadīं al-Nabawi $\bar{l}^{3}$ dengan berangkat pada kata زَ زَهَ kemudian penulis temukan beberapa informasi hadis-hadis yang mengunakan kata (lafż) زَ jَ atau derivasinya, di antaranya:

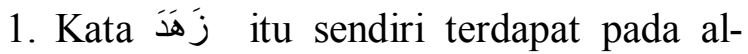
Tirmizi bab jannah hadis nomor 2; Ahmad Ibn Hanbal hadis nomor: 1, 4, 5, 60, 64, 65, 109, 266, 249, dan 378; Abū Dāwūd bab jihād hadis nomor 25; alDārimī bab muqaddimah hadis nomor 29.

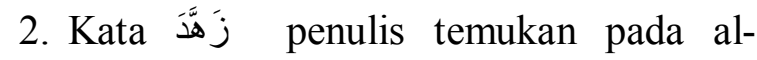
Bukhārī bab da'awāt hadis nomor 63; kitab talāq hadis nomor 24; Muslim Ibn al-Ḥajjāj pada bab jum 'ah hadis nomor 14; al-Nasāi bab jum'at hadis nomor 45; dan Ahmad Ibn Hanbal hadis nomor 2.

3. Kata آَْهَ penulis temukan pada Ahmad Ibn Hanbal hadis nomor: 2, 5, 24, 252, 290.

4. Kata نَزَ هَنَ penulis temukan pada Ahmad Ibn Hanbal hadis nomor 6, 282.

${ }^{2}$ Abdul Majid Khon, Ulumul Hadis (Jakarta: Amzah, 2010), 119.

${ }^{3}$ A. J. Wensink, Al-Mu jam al-Mufahras li alAlfāz al-Hadīs al-Nabawī (Leiden: E. J. Brill, 1943), 348-349.
5. Kata زُهْ penulis temukan pada Ibn Mājah pada kitāb zuhud hadis nomor 1 Kata زَهِ penulis temukan pada alNasāi pada bab tafsīr surat 58 nomor hadis 2. 


\begin{tabular}{|c|c|c|c|c|c|c|c|c|}
\hline \multirow{2}{*}{ No } & \multirow{2}{*}{ Nama Kitab } & \multicolumn{7}{|c|}{ Kata } \\
\hline & & زَهَدَ & زَهَدَّدَ & أَزَْْدَ & نَزَزَهَدَ & ز زهُ & زَهِيْدُ & زَ زَادَةُة \\
\hline 1. & Al-Tirmiżī & 1 & & & & & & 1 \\
\hline 2. & Aḥmad bin Hanbal & 10 & 1 & 5 & 2 & & & 6 \\
\hline 3. & Abū Dāwūd & 1 & & & & & & \\
\hline 4. & Al-Dārimī & 2 & & & & & & \\
\hline 5. & Al-Bukhārī & & 2 & & & & & \\
\hline 6. & $\begin{array}{l}\text { Muslim ibn al- } \\
\text { Hajjāj }\end{array}$ & & 1 & & & & & \\
\hline 7. & Al-Nasā'̄' & & 1 & & & & 1 & \\
\hline 8. & Ibnu Mājah & & & & & 1 & & 1 \\
\hline & Jumlah & 14 & 5 & 5 & 2 & 1 & 1 & 8 \\
\hline
\end{tabular}

Untuk memberikan pengertian secara etimologi, selanjutnya penulis mencari pengertian kata زَهَ زَهًْا - زَهَ berikut dengan derivasinya dalam kamus alMunawwir, kemudian penulis temukan di antaranya:

1. Kata Kَنْهُ زَهُدَ فِي الثَّْيْيَ اَوْ عَنْهُ: رَغِبَ artinya meninggalkan dan tidak menyukai.

2. Kata زَهَهَ فِي الدُنْنَّا artinya menjauhkan diri dari kesenangan duniawi untuk beribadah.

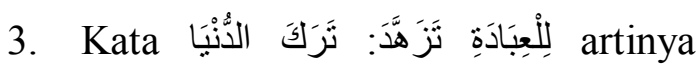
meninggalkan kesenangan dunia untuk beribadah

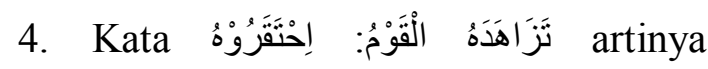
menghina, meremehkan.

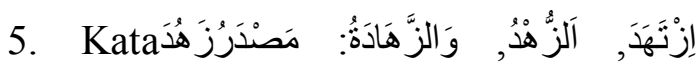
artinya memandang hina, remeh, rendah.

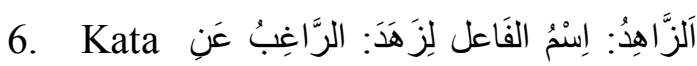

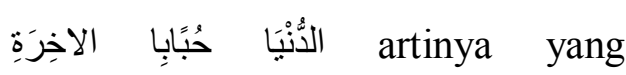
meninggalkan kehidupan atau kesenangan duniawi dan memilih akhirat

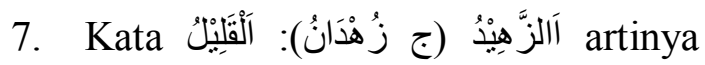

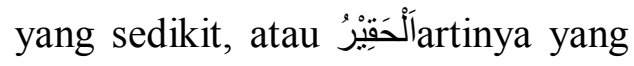
rendah, hina.

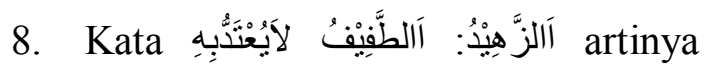
yang kecil, sedikit, tak berarti.

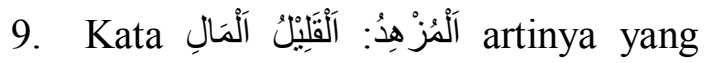
melarat, sedikit hartanya.

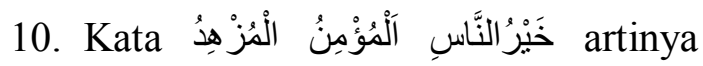
sebaik-baik orang adalah orang mukmin yang sedikit hartanya

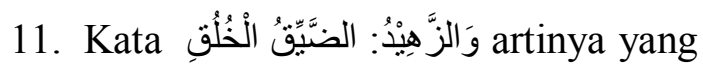
sempit pekertinya. ${ }^{4}$

12. Kata زَهَ زَهَ, diartikan menjauhkan diri dari kesenangan duniawi untuk beribadah. ${ }^{5}$

Cukup banyak varian pengertian kata zuhud tersebut. Ada zuhud yang

${ }^{4}$ Ahmad Warson Munawwir, al-Munawwir (Surabaya: Pustaka progresif, 1997), 588-589.

${ }^{5}$ Louis Makluf, Al-Munjid fì al-Lugah wa al A 'lām (Beirut-Lebanon: Dār al Masyriq, 1994), 308309. 
diartikan menghina, meremehkan, meninggalkan, tidak menyukai, menjauhkan diri dari kesenangan duniawi. Dengan banyaknya pengertian tersebut, penulis akan mencari hadis tentang zuhud yang memberikan pengertian bahwa zuhud diartikan menjauhkan diri dari kesenangan duniawi untuk beribadah. Ini perlu untuk penulis tetapkan karena sebagai acuan untuk verifikasi hadis yang memiliki matn semakna.

Ada beberapa hadis yang memiliki pengertian zuhud dengan arti tidak menyukai, tetapi lebih ditekankan pada respon terhadap orang (subyeknya), bukan pada sesuatu yang bersifat materi atau berupa kesenangan duniawi, misalnya:

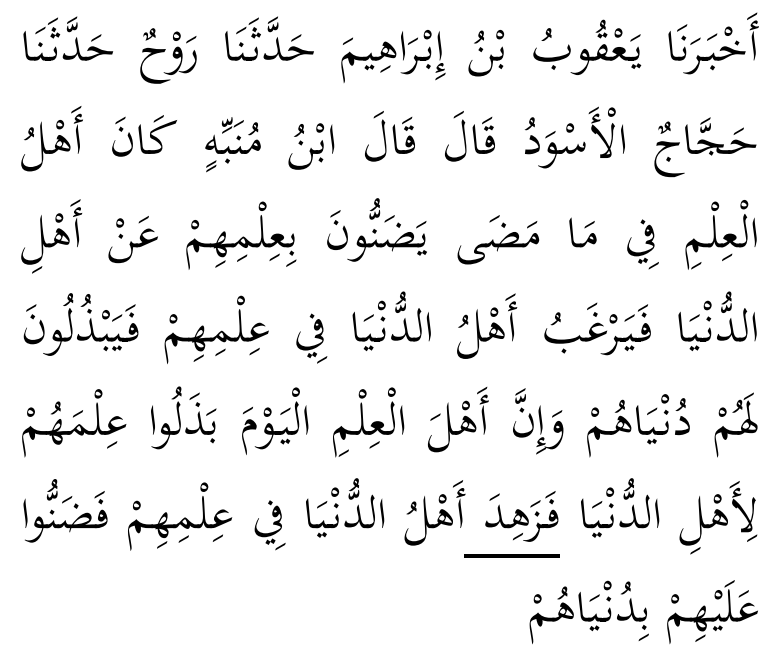

Telah mengabarkan kepada kami Ya'qub bin Ibrahim telah menceritakan kepada kami Rauh telah menceritakan kepada kami Hajjaj al-Aswad ia berkata: Ibnu Munabbih berkata: "ahl al-ilm zaman dahulu enggan mendatangi ahl al-dunyalorang yang mencintai keduniaan) untuk menyampaikan ilmu mereka, sehingga orang yang mencintai keduniaan itu menjadi suka dengan ilmu mereka, sehingga mereka mau mengeluarkan harta untuk mereka (para ulama). Sedangkan para ulama zaman sekarang, mereka menyampaikan ilmu kepada orang yang mencintai keduniaan, hingga orang yang mencintai keduniaan itu menjadi zuhud(tidak menyukai) dengan mereka, dan mereka pun enggan mengeluarkan harta untuk mereka (para ulama). ${ }^{6}$

Di sisi lain, ada juga beberapa hadis yang tidak secara langsung disandarkan kepada Rasulullah saw. Seperti halnya hadis di bawah ini:

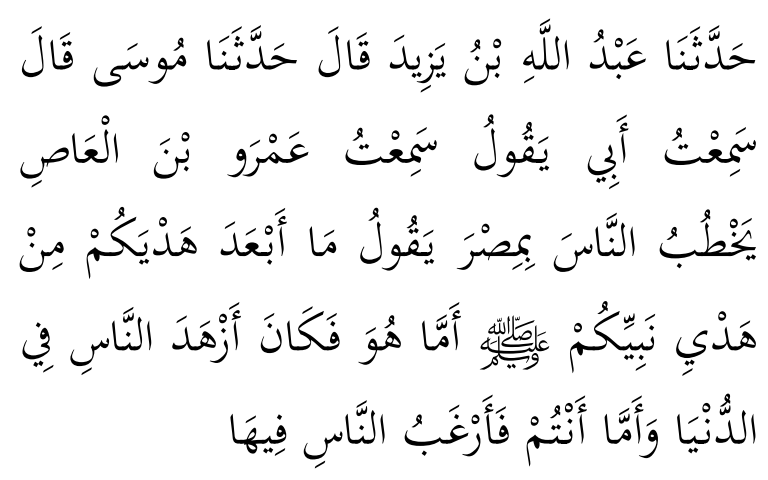

(Ahmad-17105): Telah menceritakan kepada kami Abdullah bin Yazid ia berkata, Telah menceritakan kepada kami Musa ia berkata, saya mendengar Bapakku berkata, saya mendengar Amru bin Ash berkhutbah di hadapan manusia di Mesir, ia mengatakan, "Alangkah jauhnya perilaku kalian terhadap perilaku Nabi kalian saw. Nabi saw seorang yang paling zuhud di dunia, sementara kalian adalah orang-orang yang lebih mengutamakan dunia."

${ }^{6} \mathrm{Ab} \overline{1}$ 'Abdillah ibn Bahrām al-Dārimī, Sunan al-Dārimī (Beirut: Dār al-Fikr, t.th). 
Sedangkan dalam hal ini penulis mengambil hadis-hadis sebagaimana terdapat di Mu 'jam al-Mufahras di atas, jengan mengambil pengertian kata زه atau derivasinya dengan makna "menjauhkan diri dari kesenangan duniawi untuk beribadah "yang penekanannya pada respon terhadap materi keduaniaan. Hadis tersebut di antaranya:

Hadis Pertama:

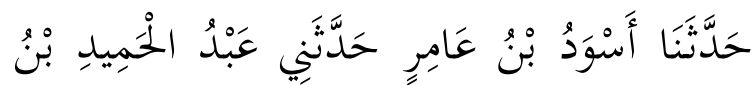

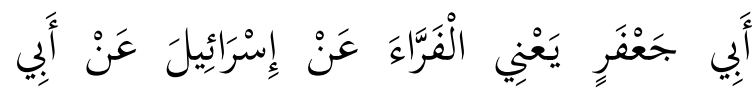

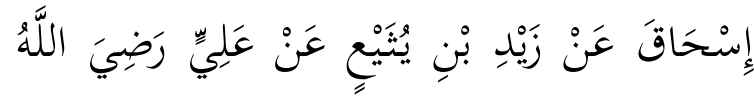
عَنْهُ قَالَ قِيلَ يَا رَسُولَ اللَّهِ مَنْ يُوَعَّرُ بَعْدَ كَقَالَ

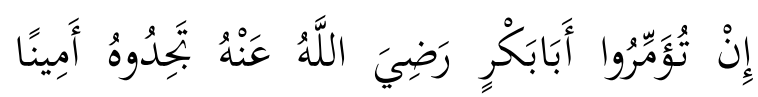

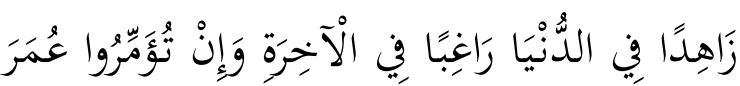

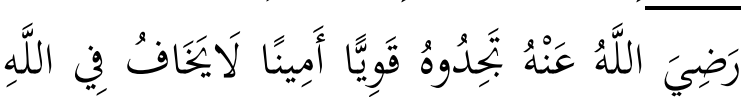

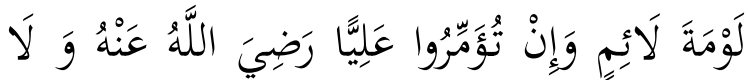

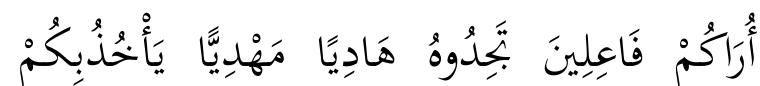

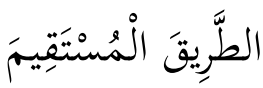

(Ahmad-817): Telah menceritakan kepada kami Aswad bin 'Amir telah menceritakan kepadaku Abd alHamid bin Abi Ja'far yaitu Al-Farra' dari Israil dari Abi Ishaq dari Zaid bin Yusai' dari Ali r.a., dia berkata; Rasulullah saw ditanya; "Wahai Rasulullah, siapa orang yang ditunjuk sebagai pemimpin setelahmu?" Beliau menjawab; "Jika kalian mengangkat Abu Bakar r.a., maka kalian mendapati dia adalah orang yang terpercaya, zuhud(isim fail-menjauhkan diri dari kesenangan duniawi untuk beribadah) terhadap dunia dan cinta pada akhirat. Jika kalian mengangkat 'Umar r.a., dia adalah orang kuat dan terpercaya, tidak takut celaan orang yang mencela. Jika kalian mengangkat 'Ali r.a., aku tidak mengira kalau kalian melaksanakannya, dia adalah orang yang memberi petunjuk dan tempat mendapat petunjuk, dia akan membawa kalian kepada jalan yang lurus".

Hadis Kedua:

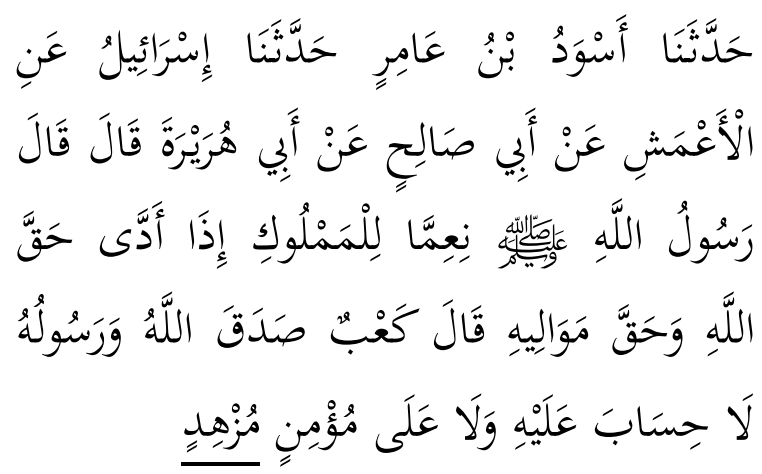

(Ahmad - 8708) : Telah menceritakan kepada kami Aswad bin 'Amir telah menceritakan kepada kami Israil dari Al-A'masy dari Abi Salih dari Abi Hurairah berkata; Rasulullah saw bersabda: "Betapa bagusnya seorang budak yang dapat melaksanakan hak Allah dan hak tuan-tuannya." Ka'ab berkata; "Betul apa yang dikatakan oleh Allah dan Rasul-Nya, tidak ada hisab baginya dan juga bagi seorang mukmin yang zuhud (isim fail-orang menjauhkan diri dari kesenangan duniawi untuk beribadah)."

Hadis Ketiga:

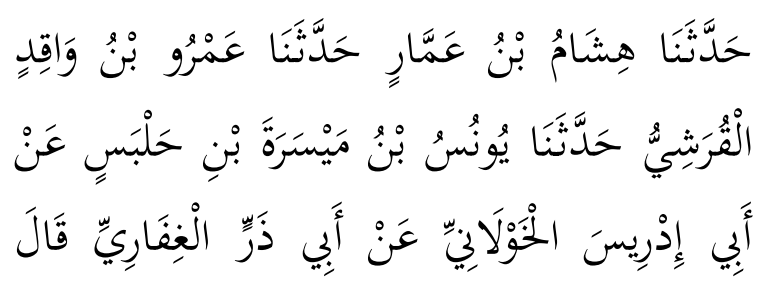




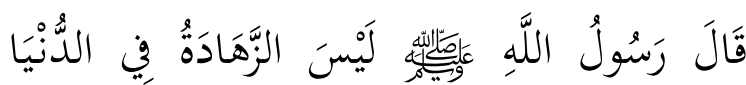

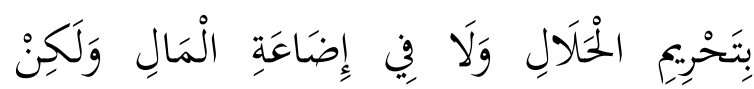

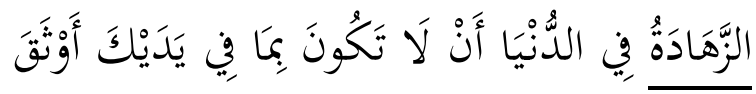

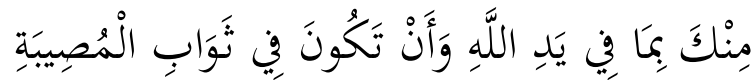

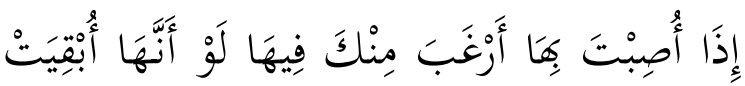

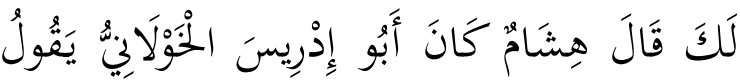

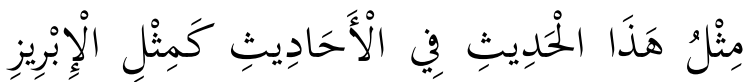
في النَّهَبِ

Telah menceritakan kepada kami Hisyam bin 'Ammar telah menceritakan kepada kami 'Amr bin Waqid al-Qurasyi telah menceritakan kepada kami Yunus bin Maisarah bin Halbas dari Abu Idris Al Khaulani dari Abu Zar al-Gifari dia berkata, "Rasulullah saw bersabda: "Tidak dikatakan zuhud (memandang hina atau remeh) terhadap dunia mengharamkan sesuatu yang halal dan tidak menghambur-hamburkan harta, tetapi zuhud (memandang hina atau remeh) terhadap dunia adalah apa yang kamu miliki tidak lebih kamu sukai dari apa yang ada di tangan Allah, dan hendaknya pahala karena sabar terhadap Musibah yang menimpamu lebih kamu sukai, dari (sekiranya) benda tersebut berada di tanganmu." Hisyam berkata, "Abu Idris al-Khaulani berkata, "Permisalan hadīis ini dengan beberapa hadìs lainnya ibarat emas murni di dalam emas biasa. ${ }^{17}$
${ }^{7} \mathrm{Abī}$ 'Abdillah Muhammad ibn Yazīd AlQazwīn̄i, Sunan Ibn Mājah (Beirut Libanon: Dār alFikr, 1995).

\section{I'tibār}

Menurut istilah ilmu hadis, i'tibar berarti menyertakan sanad-sanad yang lain untuk suatu hadistertentu, yang hadisitu pada bagian sanadnya tampak hanya terdapat seorang perawi saja. Dengan menyertakan sanad-sanad yang lain tersebut akan dapat diketahui apakah ada periwayat yang lain ataukah tidak ada untuk bagian sanad dari sanad hadis yang dimaksud. Dengan demikian, akan terlihat seluruh jalur sanad yang diteliti dengan jelas, dan juga nama-nama periwayatnya dan metode yang digunakan oleh masing-masing periwayat yang bersangkutan. ${ }^{8}$

Ada beberapa informasi dari hadis yang penulis kemukakan. Pada hadis pertama terdapat nama $\mathrm{Abu}$ Ishaq (kuniyahnya), nama lengkapnya adalah Amr bin 'Abdullah. Pada hadis kedua terdapat nama Israil, nama lengkapnya adalah Israil bin Yunus bin Abi Ishaq, kuniyahnya Abu Yusuf; terdapat pula nama Abi Salih, nama lengkapnya adalah Zakwan, kuniyahnya adalah Abu Salih; Abu Hurairah nama lengkapnya adalah Abd al-Rahman bin Syakhr. Pada hadis ketiga terdapat nama 'Amr bin Waqid al-Qurasyi, kuniyahnya adalah Abu Hafsh; Abi Idris alHaulaniy, nama lengkapnya adalah A'izullah bin 'Abdullah, kuniyahnya adalah

${ }^{8}$ M. Syuhudi Ismail, Metodologi Penelitian Hadis Nabi (Jakarta: PT. Bulan Binatang, 2007), 49. 
Abu Idris; Abi Zar al-Gifariy, nama lengkapnya adalah Jundub bin Junadah, kuniyahnya adalah Abu Zar.

Penulis sengaja mengambil dua hadis yang mukharrij-nya Imam Ahmad bin Hanbal karena merupakan mukharij yang paling banyak hadisnya dan memiliki makna sesuai dengan yang dikehendaki penulis. Adapun hadis yang ketiga penulis kemukakan sebagai contoh hadis yang memeliki relevansi dengan tema, namun memiliki derajat yang tidak sahih karena terdapat beberapa perawi yang dinilai munkar al-hadīis.

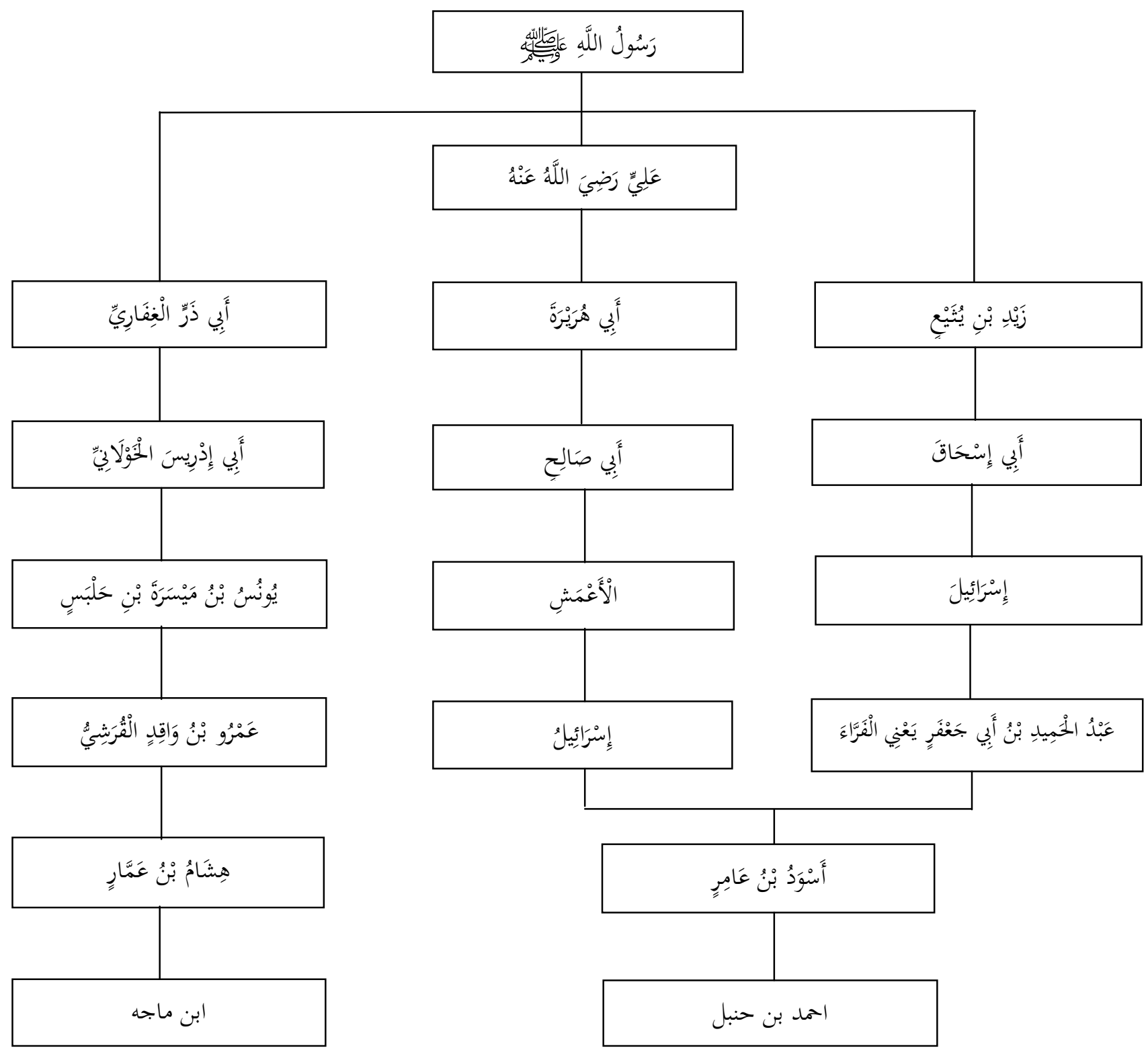


1. Biografi Perawi Hadis Pertama

a. Aswad bin 'Amir

Nama lengkapnya adalah Al-Aswad bin 'Amir. Dia termasuk tabi' al-tabi' in kalangan biasa. Kuniyahnya adalah Abu 'Abd al-Rahman. Negeri semasa dia hidup adalah Bagdad. Dia wafat pada tahun 208 H.

Komentar ulama terhadap dirinya diantaranya disampaikan oleh: Ibn alMadini mengatakan siqah; Abu Hatim mengatakan siqah; Yahya bin Ma'in mengatakan lāba'sa bih; Ibnu Sa'd mengatakan sāliḥ al-ḥadīis; Ibnu Hibban mengatakan bahwa ia disebutkan dalam alsiqah; Ibnu Hajar al-'Asalani mengatakan siqah.

b. 'Abd al-Hamid bin Abi Ja'far

Nama lengkapnya adalah Abd alHamid bin Kaisan bin Abi Ja'far. Dia termasuk kalangan tabi'in (tidak jumpa sahabat), negeri semasa hidupnya adalah Kufah.

Komentar ulama terhadap dirinya khususnya disampaikan Al-Baihaqi, dia mengatakan bahwa iamajhūl.

c. Isra'il

Nama lengkapnya adalah Isra'il bin Yunus bin Abi Ishaq. Dia termasuk kalangan tabi' al-tabi'in khususnya kalangan tua.Kuniyahnya adalah Abu Yusuf.Negeri semasa hidupnya adalah Kufah.Dia wafat pada tahun $160 \mathrm{H}$.
Komentar ulama terhadap dirinya diantaranya disampaikan oleh: Ibnu Hibban mengatakan bahwa dia disebutkan dalam al-siqah; Ibnu Hajar al-'Asqalani mengatakan siqah.

d. Abu Ishaq

Nama lengkapnya adalah Amr bin 'Abdullah. Dia termasuk kalangan tabi'in khususnya kalangan pertengahan. Kuniyahnya adalah Abu Ishaq. Negeri semasa dia hidup adalah di Kufah. Dia wafat pada tahun $128 \mathrm{H}$.

Komentar ulama terhadap dirinya diantaranya disampaikan oleh: Ahmad bin Hanbal mengatakan siqah; Yahya bin Ma'in mengatakan siqah; al-Zahabi mengatakan ahad al-ahlām.

e. Zaid bin Yusai'

Nama lengkapnya adalah Zaid bin Yasai'. Dia termasuk kalangan tabi'in kalangan tua.Negeri semasa hidupnya adalah Kufah.

Komentar ulama terhadap dirinya disampaikan oleh: Al-“Ajli mengatakan dia siqah; Ibnu Sa'd mengatakan hadisnya sedikit; Ibnu Hibban mengatakan bahwa dia disebutkan dalam siqah.

f. 'Ali bin Abi Thalib

Nama lengkapnya adalah 'Ali bin Abi Thalib bin 'Abd al-Mutalib bin Hasyim bin 'Abd al-Manaf. Dia termasuk kalangan sahabat.Kuniyahnya adalah Ali alHasan.Negeri semasa hidupnya adalah di 
Kufah.Dia wafat pada tahun 40 H.Komentar ulama bahwa dia adalah seorang sahabat.

2. Biografi Perawi Hadis Kedua

a. Aswad bin 'Amir

Nama lengkapnya adalah Al-Aswad bin 'Amir. Dia termasuk kalangan tabi' altabi'in khususnya kalangan biasa. Kuniyahnya adalah Abu 'Abd al-Rahman. Negeri semasa hidupnya berada di Baghdad. Dia wafat pada tahun $208 \mathrm{H}$.

Komentar ulama terhadap dirinya di antaranya disampaikan oleh: Ibnu al-Madini mengatakan siqah; Abu Hatim mengatakan dia siqah: Yahya bin Ma'in mengatakan $l \bar{a}$ ba'sa bih; Ibnu Sa'd mengatakan sālị̣ alhadīis; Ibnu Hibban mengatakan dia disebutkan dalam siqah; Ibnu Hajar mengatakan dia siqah.

b. Isra'il

Nama lengkapnya adalah Isra'il bin Yunus bin Abi Ishaq. Dia termasuk kalangan tabi' al-tabi'in khususnya kalangan tua. Kuniyahnya adalah Abu Yusuf. Negeri semasa hidupnya berada di Kufah. Dia wafat pada tahun $160 \mathrm{H}$.

Komentar ulama terhadap dirinya diantaranya disampaikan oleh: Ibnu Hibban mengatakan bahwa dia disebutkan dalam siqah; Ibnu Hajar Al-'Asqalani mengatakan dia siqah.

c. Sulaiman bin Mihran
Nama lengkapnya adalah Sulaiman bin Mihram. Dia termasuk kalangan tabi' in kalangan biasa. Kuniyahya adalah Abu Muhammad. Negeri semasa dia hidup adalah Kufah. Dia wafat pada tahun $147 \mathrm{H}$.

Komentar ulama terhadap dirinya diantaranya disampaikan oleh: Al-'Ajli mengatakan dia siqah sabat; AlNasa'imengatakan siqah sabat; Yahya bin Ma'in mengatakan dia siqah; Ibnu Hibban mengatakan bahwa dia disebutkan dalam siqah; Ibnu Hajar Al- 'Asqalani mengatakan dia siqahdan ḥāfiz.

d. Abi Salih

Nama lengkapnya adalah Zakwan. Dia termasuk kalangan tabi'in khususnya kalangan pertengahan. Kuniyahnya adalah Abu Salih. Negeri semasa dia hidup berada di daerah Madinah. Dia wafat pada tahun $101 \mathrm{H}$.

Komentar ulama terhadap dirinya di antaranya disampaikan oleh: Abu Zur'ah mengatakan mustaqīm al-hadīis; Muhammad bin Sa'd mengatakan siqah dan banyak hadīis-nya; Al-Saji mengatakan siqah șadūq.

e. Abu Hurairah

Nama lengkapnya adalah Abd alRahman bin Syakhr. Dia termasuk kalangan sahabat. Kuniyahnya adalah Abu Hurairah. Negeri semasa dia hidup adalah Madinah. Dia wafat pada tahun $57 \mathrm{H}$. 
Komentar ulama, khususnya disampaikan oleh Ibnu Hajar al-'Asqalani, dia mengatakan bahwa ia termasuk golongan sahabat.

\section{Biografi Perawi Hadis Ketiga}

a. Hisyam bin 'Ammar

Nama lengkapnya adalah Hisyam bin 'Ammar bin Nusair bin Maisarah bin Aban. Dia termasuk kalangan tabi'in khususnya pada kalangan biasa. Adapun kuniyahnya adalah Abu Al-Walid. Daerah atau negeri semasa hidupnya adalah di daerah Syam. Dia wafat pada tahun $245 \mathrm{H}$.

Komentar beberapa ulama terhadap Hisyam bin 'Ammar cukup banyak, diantaranya adalah: Yahya bin Ma'in mengatakan siqah; Al-'Ajli mengatakan dia siqah; Abu Hatim mengatakan dia kaisun; Al-Nasa'i mengatakan lā ba'sa bih; Ibnu Hibban menyatakan dia disebutkan dalam siqah; Ibnu Hajar Al-'Asqalani mengatakan șadūq; dan Al-Zahabi mengatakan dia adalah hăafiz.

b. 'Amr bin Waqid al-Qurasyiy

Nama lengkapnya adalah 'Amr bin Waqid. Dia termasuk kalangan tabi' in sehingga tidak menjumpai sahabat. Kuniyahnya adalah Abu Hafsh. Daerah atau negeri semasa hidupnya di wilayah Syam.

Komentar ulama terhadap 'Amr bin Waqid al-Quraisyiy di antaranya disampaikan oleh: Abu Hatim mengatakan dia ḍa'iff al-ḥadìs; Al-Bukhari mengatakan dia termasuk munkar al-ḥadìs; Al-Tirmizi mengatakan dia munkar al-ḥadìs, Al-Nasa'i mengatakan dia matrūk al-ḥadīis; AlDaruqutni mengatakan dia matrūk al-hadīis Ibnu Hajjar Al-'Asqalani mengatakan dia matrūk, Al-Zahabi mengatakan bahwa dia meninggalkannya.

c. Yunus bin Maisarah bin Halbas

Nama lengkapnya adalah Yunus bin Maisarah bin Halbas. Dia termasuk kalangan tabi'in, khususnya kalangan pertengahan. Kuniyahnya adalah Abu 'Ubaid. Adapun negeri semasa hidupnya di daerah Syam. Dia wafat pada tahun $132 \mathrm{H}$.

Komentar ulama terhadap Yunus bin Maisarah bin Halbas di antaranya disampaikan oleh: Ibnu Sa'd mengatakan dia siqah; Al-'Ajli mengatakan dia siqah; Abu Daud mengatakan dia siqah; AlDaruqutni mengatakan dia siqah; Ibnu Hibban mengatakan bahwa dia disebutkan dalam al-siqah; Ibnu Hajar Al-'Asqalani mengatakan dia siqah dan ahli ibadah; AlZahabi mengatakan dia siqah.

d. Abi Idris al-Haulaniy

Nama lengkapnya adalah A'izullah bin 'Abdullah. Dia termasuk kalangan tabi'in khususnya kalangan tua. Kuniyahnya adalah Abu Idris. Negeri atau daerah semasa hidupnya di Syam. Dia wafat pada tahun $80 \mathrm{H}$. 
Komentar ulama terhadap Abi Idris al-Haulaniy di antaranya disampaikan oleh: Abu Hatim mengatakan dia siqah; Ibnu Sa'd mengatakan dia siqah; Al-'Ajli mengatakan dia siqah; Ibnu Hibban menyatakan dia siqah; Al-Zahabi mengatakan bahwa dia adalah seorang tokoh.

\section{e. Abi Zar al-Gifariy}

Nama lengkapnya adalah Jundub bin Junadah. Dia termasuk kalangan sahabat. Kuniyahnya adalah Abu Zar. Negeri semasa hidup berada di Madinah. Dia wafat pada tahun $32 \mathrm{H}$. Adapun komentar ulama terhadapnya bahwa dia adalah sahabat.

Berdasarkan informasi dari biografi perawi dan penilaian ulama terhadap perawi tersebut, maka hadis pertama dan kedua bisa kita kategorikan sebagai hadis sahih dengan alasan bahwa berdasarkan komentar para ulama terhadap para perawi adalah siqah, kecuali terdapat pada hadis nomor 3 tepatnya pada perawi 'Amr bin Waqid alQurasyiy dengan komentar ulama yang di antaranya disampaikan oleh: Abu Hatim mengatakan dia da'îf al-ḥadìs; Al-Bukhari mengatakan dia termasuk munkar al-hadīis; Al-Tirmizi mengatakan dia munkar alhadīis, Al-Nasa'i mengatakan dia matrūk alhadīis; Al-Daruqutni mengatakan dia matrūk al-ḥadïs Ibnu Hajjar Al-'Asqalani mengatakan dia matrūk, Al-Zahabi mengatakan bahwa dia meninggalkannya. Tentunya hal ini mempengaruhi terhadap kualitas hadīs tersebut.

Di sisi lain, adanya indikasi kuat perjumpaan para perawi tersebut dengan melihat tahun wafat mereka yang diperkirakan adanya pertemuan atau bersamaan. Dalam hal ini kecuali hadis nomor 3, bisa kita lihat tahun wafat antara Hisyam bin 'Ammar (245 H) dengan Yunus bin Maisarah bin Halbas (132 H) terpaut cukup jauh.

\section{Kritik Matn $\boldsymbol{H} \boldsymbol{G a d} \bar{\imath} \dot{s}$}

Hadis-hadis di atas berbicara tentang zuhud dalam pengertian menjauhkan diri dari kesenangan duniawi untuk beribadah. Di mana pengertian zuhud tersebut sesuai dengan yang disebutkan dalam Alquran Surat Ibrahim/14: 3:

(Yaitu) orang-orang yang lebih menyukai kehidupan dunia dari pada kehidupan akhirat, dan menghalanghalangi (manusia) dari jalan Allah dan menginginkan agar jalan Allah itu bengkok. Mereka itu berada dalam kesesatan yang jauh. ${ }^{9}$ (Q.S. Ibrahim/14: 3).

Melihat dari tinjauan matan hadis yang didukung oleh ayat Alquran tersebut, ini menunjukkan bahwa Islam benar-benar menyeru umat Islam untuk lebih mencintai kehidupan akhirat daripada kehidupan

${ }^{9}$ Departemen Agama RI, Al-Qur'an dan Terjemahnya (Jakarta: PT. Sygma Examedia Arkanleema, 2009), 255. 
dunianya. Dengan demikian hadis ini bisa diterima karena tidak bertentangan dengan Alquran.

\section{Syarah Hadīis}

1. Esensi zuhud

Cinta yang berlebihan pada dunia dinisbatkan oleh Alquran pada sifat orang kafir yang ingkar kepada Tuhan, dalam Surat Ibrahim/14: 3.

Kemudian benarkah konsep zuhud yang diajarkan oleh para sufi itu adalah zuhud adalah identik dengan kemiskinan, kebodohan, keterbelakangan dan yang berujung pada suatu keyakinan bahwa dunia itu adalah musuh bagi manusia, menghalangi manusia dari Tuhannya sehingga harus ditinggalkan demi mencapai kepuasan batin serta bisa mendekatkan diri pada-Nya. Logika awam yang normal dan sehat tentu akan menjawab "tidak". Bukankah Allah swt. sewaktu pertama kali menciptakan manusia adalah ditujukan untuk menjadi khalifah pengatur didunia ini. Dan untuk menjadi seorang khalifah yang dapat mengatur dunia seisinya ini dengan baik tentu diperlukan teori-teori dari berbagai disiplin ilmu pengetahuan dan diperlukan langkah kongrit untuk mengaplikasikannya. Bukankah Alquran sendiri dalam surat al- A'raf ayat 32 dengan tegas mengatakan:
Katakanlah: "Siapakah yang mengharamkan perhiasan dari Allah yang Telah dikeluarkan-Nya untuk hamba-hamba-Nya dan (siapa pulakah yang mengharamkan) rezki yang baik?" Katakanlah: "Semuanya itu (disediakan) bagi orang-orang yang beriman dalam kehidupan dunia, khusus (untuk mereka saja) di hari kiamat." Demikianlah kami menjelaskan ayat-ayat itu bagi orangorang yang Mengetahui. ${ }^{10}$

Sehingga konsep zuhud dengan pengertian harus terputus dari segala hal-hal keduniawian semata, jelas bertentangan dengan konsep Alquran itu sendiri walaupun disana ada beberapa ayat lain yang menerangkan kadar bahaya dari dunia tatkala tidak disikapi dengan perasaan sekedar sebagai ajang mediator untuk mencari bekal pada kehidupan abadi di akhirat nanti.

Al-Imam Gazali menerangkan di dalam Ihya' bahwa hakekat zuhud bukanlah meninggalkan harta benda dan mengorbankannya pada jalur sosial untuk menarik perhatian manusia, itu menurut beliau hakikatnya hanyalah sebagian dari perhiasan adat, namun sama sekali tidak ada hubungannya dengan nilai ibadah, karena hal ini biasanya dimulai dengan niat mengharapkan ganti yang lebih atau karena tendensi ingin dikenal dalam suatu komunitas sosial, juga karena ingin pujian supaya dikenal sebagai seorang darmawan

\footnotetext{
${ }^{10}$ Departemen Agama RI, Al-Qur'an, 154.
} 
dan sebagainya. Namun orang yang zuhud itu adalah orang yang mempunyai harta benda akan tetapi dia menyikapinya dengan lapang dada walaupun dia mampu untuk menikmati hartanya itu tanpa suatu kekurangan apapun, namun dia lebih memilih bersikap waspada, hatinya tidak ikut condong ke harta, hatinya tidak terlalu terikat dengan harta, karena dia khawatir sikap condongnya itu akan membawanya cinta kepada selain Allah swt., dan mencintai selain dari Allah swt. berarti dia telah membuat sekutu dalam cintanya itu.

Memang terdapat ayat yang memberikan peringatan kepada kita tentang seharusnya bagaimana sikap kita terhadap dunia. Sebagaimana firman Allah suratalHadid/57: 20-23:

Ketahuilah, bahwa sesungguhnya kehidupan dunia Ini hanyalah permainan dan suatu yang melalaikan, perhiasan dan bermegahmegah antara kamu serta berbanggabanggaan tentang banyaknya harta dan anak, seperti hujan yang tanamtanamannya mengagumkan para petani; Kemudian tanaman itu menjadi kering dan kamu lihat warnanya kuning Kemudian menjadi hancur. dan di akhirat (nanti) ada azab yang keras dan ampunan dari Allah serta keridhaan-Nya. dan kehidupan dunia Ini tidak lain hanyalah kesenangan yang menipu. Berlomba-lombalah kamu kepada (mendapatkan) ampunan dari Tuhanmu dan syurga yang luasnya seluas langit dan bumi, yang disediakan bagi orang-orang yang beriman kepada Allah dan rasul-
rasul-Nya. Itulah karunia Allah, diberikan-Nya kepada siapa yang dikehendaki-Nya. dan Allah mempunyai karunia yang besar. Tiada suatu bencanapun yang menimpa di bumi dan (Tidak pula) pada dirimu sendiri melainkan Telah tertulis dalam Kitab (Lauhul Mahfuzh) sebelum kami menciptakannya. Sesungguhnya yang demikian itu adalah mudah bagi Allah. (Kami jelaskan yang demikian itu) supaya kamu jangan berduka cita terhadap apa yang luput dari kamu, dan supaya kamu jangan terlalu gembira terhadap apa yang diberikan-Nya kepadamu. dan Allah tidak menyukai setiap orang yang sombong lagi membanggakan diri. ${ }^{\text {II }}$ (Q.S. Al-Hadid/57: 20-23).

Ayat di atas tidak menyebutkan kata zuhud, tetapi mengungkapkan tentang makna dan hakikat zuhud. Ayat ini menerangkan tentang hakikat dunia yang sementara dan hakikat akhirat yang kekal. Kemudian menganjurkan orang-orang beriman untuk berlomba meraih ampunan dari Allah dan surga-Nya di akhirat. Selanjutnya Allah menyebutkan tentang musibah yang menimpa manusia adalah ketetapan Allah dan bagaimana orang-orang beriman harus menyikapi musibah tersebut. Sikap yang benar adalah agar tidak mudah berduka terhadap musibah dan apa saja yang luput dari jangkauan tangan. Selain itu, orang yang beriman juga tidak terlalu gembira sehingga hilang kesadaran terhadap apa yang didapatkan. Begitulah

\footnotetext{
${ }^{11}$ Departemen Agama RI, Al-Qur'an, 154.
} 
metodologi Alquran ketika berbicara tentang nilai-nilai dan prinsip-prinsip yang mengarahkan manusia untuk bersikap zuhud. Dari ayat itu juga, kita mendapat pelajaran bahwa akhlak zuhud tidak mungkin diraih kecuali dengan mengetahui hakikat dunia yang bersifat sementara, cepat berubah, rendah, hina dan bahayanya ketika manusia mencintanya.

\section{Tingkatan zuhud}

Menurut Abu Nasr As Sarraj At Tusi ada 3 tingkatan zuhud. Pertama, tingkat Mubtadi' (tingkat pemula) yaitu orang yang tidak memiliki sesuatu dan hatinya pun tidak ingin memilikinya; kedua, tingkat Mutaḩaqqiq yaitu orang yang bersikap tidak mau mengambil keuntungan pribadi dari harta benda duniawi karena ia tahu dunia ini tidak mendatangkan keuntungan baginya; ketiga, tingkat 'Ālim Muyaqqin yaitu orang yang tidak lagi memandang dunia ini mempunyai nilai, karena dunia hanya melalaikan orang dari mengingat Allah.

AI-Gazali membagi zuhud juga dalam tiga tingkatan yaitu: pertama, zuhud meninggalkan sesuatu karena menginginkan sesuatu yang lebih baik dari padanya; kedua, meninggalkan keduniaan karena mengharap sesuatu yang bersifat keakhiratan; ketiga meninggalkan segala sesuatu selain Allah karena terlalu mencintai-Nya.

Dari keterangan di atas dapat dipahami bahwa seakan-akan harta benda adalah sesuatu yang harus dihindari karena dianggap dapat memalingkan hati, dari mengingat tujuan perjalanan sufi yaitu Allah, padahal zuhud bukan berarti sematamata tidak mau memiliki harta benda dan tidak suka mengenyam nikmat duniawi, tetapi sebenarnya adalah kondisi mental yang tidak mau terpengaruh oleh harta dan kesenangan duniawi dalam mengabdikan diri kepada Allah.

Para ulama memperjelas makna dan hakikat zuhud. Secara syar'i, zuhud bermakna mengambil sesuatu yang halal hanya sebatas keperluan. Abu Idris AlKhaulani berkata, "Zuhud terhadap dunia bukanlah mengharamkan yang halal dan membuang semua harta. Akan tetapi zuhud terhadap dunia adalah lebih menyakini apa yang ada di sisi Allah ketimbang apa yang ada di tangan kita.

\section{Kesimpulan}

Bahwa term zuhud dalam pengertian menjauhkan diri dari kesenangan duniawi untuk beribadah kepada Allah terdapat dalam beberapa hadis Rasulullah dan juga terdapat dalam Alquran.

Zuhud dengan pengertian harus terputus dari segala hal-hal keduniawian 
semata, jelas bertentangan dengan konsep Alquran itu sendiri walaupun di sana ada beberapa ayat lain yang menerangkan kadar bahaya dari dunia tatkala tidak disikapi dengan perasaan sekedar sebagai ajang mediator untuk mencari bekal pada kehidupan abadi di akhirat nanti. Namun orang yang zuhud diperbolehkan mempunyai harta benda akan tetapi dia menyikapinya dengan lapang dada walaupun dia mampu untuk menikmati hartanya itu tanpa suatu kekurangan apapun, namun dia lebih memilih bersikap waspada, hatinya tidak ikut condong ke harta, hatinya tidak terlalu terikat dengan harta, karena dia khawatir sikap condongnya itu akan membawanya cinta kepada selain Allah swt., dan mencintai selain dari Allah swt berarti dia telah membuat sekutu dalam cintanya itu.

\section{Daftar Pustaka}

Al-Dārimī, Abī 'Abdillah ibn Bahrāmī. Sunan al-Dārimī. Beirut: Dār al-Fikr, t.th.

Departemen Agama RI. Al-Qur'an dan Terjemahnya.Jakarta: PT. Sygma Examedia Arkanleema, 2009.

Ismail, M. Syuhudi. Metodologi Penelitian HadisNabi. Cet. I; Jakarta: Bulan Bintang, 1992. . Metodologi Penelitian Hadis Nabi. Jakarta: PT. Bulan Binatang, 2007.

Khon, Abdul Majid. Ulumul Hadis. Jakarta: Amzah, 2010.

Makluf, Louis. Al-Munjid fì al-Lugah wa al A 'lām. Beirut-Lebanon: Dār al Masyriq, 1994.

Munawwir, Ahmad Warson. Al-Munawwir.Surabaya: Pustaka progresif, 1997.

al-Qazwīn̄̄, Abī 'Abdillah Muhammad ibn Yazīd. Sunan Ibn Mājah. Beirut Libanon: Dār alFikr, 1995.

Wensink, A. J. Al-Mu 'jam al-Mufahras li al-Alfāz al-Hadīs al-Nabawī. Leiden: E. J. Brill, 1943. 